interest him, and his versatility is illustrated by helpfulness in various educational problems, it may be counselling non-scientific faculties of several colleges as to advantageous research problems, or perchance, advising the Board of 'Trade of a 'textile' city, during the present collapse of industrial values, as to the most judicious expenditures for educational purposes.

It is not generally known that Dr. Shapley's most interesting recreation is the study of ants. For two years on Mount Wilson, he observed and studied the habits of trail-running ants, seventy thousand of them on some summer days going along each file. Under varying atmospheric conditions, he measured their speed at fixed intervals of distance. The fact was established that their speed is a function of temperature alone, and increases fifteen fold with an increase of $30^{\circ} \mathrm{C}$. in air temperature. Conversely, a single observation of the ant-speed led to the prediction of the temperature within $1^{\circ} \mathrm{C}$. Thus to his 'period-luminosity' and 'spectrum-period' relations among the stars, he added the 'speed-temperature' relation among ants. Descriptions of some of these observations will be found in the paper "Thermo. kineties of Liometopum apiculatum Mayr", published in the Proceedings of the National Academy of Sciences for April 1920. Dr. Shapley has also studied the morphology of ants, as evidenced by his large collection of worker ants with wing vestiges, described in a "Note on Pterergates in the Californian Harvester Ant" (Psyche, 27, No. 4).

Perhaps his study of ants taught Dr. Shapley not only speed, but also conservation of energy, for with all his other activities, he has found time to compile the "Source Book in Astronomy" and to write books, such as "Star Clusters", and five chapters in the "Universe of Stars", a pioneer series of radio talks given in 1925 by members of the Observatory staff. As a lecturer either at universities or before the general public, he is very successful. Why this is so may be readily understood by reading his small books "Sidereal Explorations" and "Flights from Chaos" based on lectures given at the Rice Institute of Texas, and the University of the City of New York.
A. J. C.

\title{
Scientific Research in Relation to Patents in the United States*
}

GINCE the War, scientists have been called $S$ upon by industry in increasing numbers for assistance in overcoming technical difficulties involving such problems as improving old products or processes, or devising entirely new products. This dependency of industry upon science has been par. ticularly marked in the chemical and electrical fields, where large industrial research laboratories have been established for investigating all phases of the products of their respective organisations. From their original task of mere laboratory control of the manufactured products, these industrial laboratories have extended their sphere of activity to such a large extent as to include research in the fundamental sciences. Industrial leaders have come to realise that fundamental research may be of vital importance to industry, for it may revolutionise existing practices or create new ones in the most unexpected quarters.

\section{Patentable Inventions other than Medicat}

These increasing contacts of scientists with the problems of industry have brought to the fore the difficult problem of adequate remuneration for their services, as well as the problem of giving the public the effective benefit of their work. In many cases valuable solutions have been made to difficulties, which were patentable. Scientists have also begun to realise that many of the fruits of their research have valuable industrial applications which can be patented. The troublesome questions thus arise: Should they proceed to obtain patents? What are the advantages in doing this ? What are the disadvantages ? A good deal of discussion has already occurred on these questions, but no definite policy has yet been formulated. The investigator who takes advantage of our patent laws is perfectly warranted in his act not only for any possible financial returns but also for the good of the public. The obtaining of some remuneration from a patent

* From "The Protection by Patents of Scientifle Discoveries", being the Report of the Committee on Patents, Copyrights and Trade Marks. Joseph Rossman (Chairman), F. G. Cottrell, A. W. Hull and A. F. Woods. Occasional Publications of the American Association for the Advancement of Science. No. 1, January, 1934. Supplement to Science, vol. 79. (New York: The Science Press.) 50 cents. is no more debasing or tainted with commercialism than the acceptance of copyright royalties from a text-book or even receiving a salary for teaching. We are at present living in an economic structure in which the making of legitimate profit is a fundamental assumption.

There are many advantages in securing patents for important advances, as only by means of patents can the legal right be secured to exclude others from practising a given process or commercialising a new product. By having such control of new discoveries the investigator is assured that his results will be used only for proper and meritorious purposes. $\mathrm{He}$ can prevent the exploitation of the public by dictating the terms under which his patent should be worked and even control the character of the commercial advertising.

\section{Medical Patents}

The committee recognises the fact that there exists in many quarters a strong feeling against medical patents. This feeling seems to be largely due to the unpleasant memories of the past exploita. tion of the public by means of 'patent medicines' which had doubtful or decidedly harmful effects on the public health. Government regulation during recent years has eliminated a great deal of misrepresentation and false claims in regard to this class of goods. The Patent Office, moreover, now seldom issues patents for the old-fashioned type of patent medicines. It is therefore an error to class all medical patents with the former types of 'patent medicines'.

The mere fact that medical patents offer the means of making profits is not a sufficient reason to con. demn them entirely. It must be remembered that patents have other very important uses. Moreover, we must bear in mind that it is possible to obtain profits from medical diserveries in many other ways without resorting tc patents if the medical investigator is so inclined. We must, after all, depend upon the integrity and cl aracter of the investigator when important medical discoveries are involved.

The ideal to strive for may perhaps be that no 
medical discoveries should be subject to any restrictions whatsoever. In our present commercial economic system, however, and with existing laws and business practices, such an ideal is difficult to attain, since not all may live up to it. We must, therefore, guide ourselves in accordance with the economic situation that exists to-day and seek to attain our ideals through the existing economic machinery rather than to ignore it entirely on the ground of ethical consideration alone.

The act of securing patents for medical discoveries is not unethical in itself, and such act does not necessarily mean that personal profits are sought. Under our existing laws and commercial practices dedication to the public of important medical discoveries by mere publication is not always the best procedure to follow. The public can often be best served by receiving the benefits of a new medical discovery under the control of a patent. Through making a medical discovery it may become the duty of the investigator to make sure by means of patents that the public will actually benefit from his discovery and not be subjected to unfair exploitation by others who may commercialise his discovery.

\section{Non-patentable Scientific Discoveries}

The proposal that the discoveries of scientists be given some legal protection appears on its face to be very reasonable and plausible. It would seem that scientists should be the first to desire such rights as a means of receiving compensation for their contributions to industry and society. A careful analysis of the whole problem, however, has led the committee to the opinion that no effort should at present be made to develop a plan for protecting scientific property. There appears to be no need for such legal protection from the view-point of incentive to the scientist or public policy. The Committee recognises that the present economic crisis has tremendously diminished the normally available funds for carrying on research so that other sources of potential funds are to be carefully considered at this time. It believes, however, that the legal and practical difficulties involved in enforcing any scientific property would eventually arouse an unfavourable public opinion against scientists, owing to the difficulty of enforcing scientific property and the inherent nature of its broad monopoly. The results of irksome scientific monopolies would react to the disadvantage of scientists and thus defeat the very purpose for which this proposal is made.

\section{University and Educational Intelligence}

CAmbridge.-The Jane Ellen Harrison Memorial Lecture will be given on May 5 at 5 p.m. in the College Hall, Newnham College, by Dr. L. S. B. Leakey, of St. John's College. The subject of the lecture will be "The Problem of the Origin of Man".

Prof. Buxton has been appointed to represent the University at the Twelfth International Veterinary Congress to be held in Now York in August.

School libraries in the United States are credited with having contributed in no small measure to the improvement in efficiency which has taken place in the schools in the last three decades. According to the Dean of the Graduate Library School of the University of Chicago, Dr. L. R. Wilson, whose views on increasing the significance of the school library are published in School and Society of December 30, the once prevalent use of the single textbook recitation procedure has been superseded by a method of instruction by which many books and materials are. studied. Although his theme is the development and fuller utilisation of the school library, his argument implies that its functions are already of great importance. He refers, for example, to the librarian's "responsibility of co-ordination and generalship in the field of supervised study" and to the library being "the principal integrating agency of the entire school". He mentions as deserving imitation the present effort on the part of the librarians of colleges and secondary schools in the Southern States to work out a co-operative plan for supplying school library facilities in rural areas. $\mathrm{He}$ advocates the provision, in library schools or teachers' colleges, of training for the part-time teacher-librarian in small schools, and the investigation of a number of problems relating to the school library which, he says, have as yet been only slightly considered. These he proceeds to discuss under the headings : administration, teaching the use of books in libraries, standards for school library service, distribution of library resources, measurement of school library influences. During the past twelve months, the Journal of Education (London) has published a series of articles, by specialists in various subjects, on the library requirements of secondary and public schools in Great Britain.

TENDENCres in university education are discussed in the John Adams lecture given in the Institute of Education, University of London, on October 10 by Dr. E. Deller, principal of the University (London : Oxford University Press. 1s.). Dr. Deller examines some of the implications of the growth in number of students which has marked the recent history of so many universities. He discerns a danger of overmechanisation, and a menace to academic freedom. University administration is susceptible of hypertrophy, as in those Russian institutions where the head is a director, responsible in the same way as the controller of a factory. Extensive student enrolment has led in Germany, where the number of unemployed graduates has been estimated to be 90,000 , to other perils: "The unjversity is to-day a temporary haven of refuge," said Prof. Dibelius recently, "for innumerable individuals who otherwise as soon as their school years were over, would sink to the ranks of the proletariat ... what a dangerous mass of inflammatory, revolutionary material and social embitterment are heaping themselves up now in those old homes of German culture." The number of students in England is not as yet, Dr. Deller thinks, excessive, but he holds that the line of advance for the future must be qualitative rather than quantitative. How views as to the proper functions of a university increasingly diverge he shows by quoting from "The University in a Changing World" : in Russia and Italy, and more recently in Germany also, the view prevails that all learning must be related to the dominant political creed. He suggests that universities can best help forward the rehabilitation of a distressful world by ascertain. ing truth rather than by attempting the adjustments and compromises, which are the proper task of the statesman, and also by extra-mural teaching. 